\title{
COMPARATIVE STUDIES ON YIELD AND QUALITY RESPONSE OF SOIL AND SOILLESS GROWN TOMATOES: THE CASE STUDY OF MASIPHATHISANE COMMUNITY PROJECT AND BATHURST EXPERIMENTAL FARM
}

\author{
Bozo, T. T. ${ }^{1}$, Mpambani, B. ${ }^{2}$, Mbenga, A. ${ }^{3}$ and Mhlontlo, S. ${ }^{4}$ \\ Correspondence author: T. T. Bozo. Email: Thozama.bozo@drdar.gov.za
}

\begin{abstract}
Tomato (Solanum lycopersicum L) belongs to the Solanaceae family and is grown worldwide for its edible fruits with antioxidant benefits. A study was conducted in Bathurst Experimental Farm and Masiphathisane Community Project to compare yield and quality of tomato cultivars cultivated with an open bag hydroponic (soilless) system and in-soil system respectively both under a semi-controlled environment. Three tomato cultivars under soilless system, namely Mercury, Merya and Star 9037, and one cultivar, SV4129, in-soil system were used. Marketable and unmarketable yield, total soluble solids (\%Brix), as well as the pH of the tomato juice were determined. Results showed that plants in the soilless system developed faster with higher total yield compared with in-soil cultivation. Cultivars Mercury and Merya can be selected and recommended for high yields and high sugar content in \%Brix respectively in soilless production. The pH of tomato juice was highest in all cultivars under soilless and the lowest was recorded in-soil production systems. The most promising cultivar with regards to yield and quality under soilless production was Mercury. Results indicate that soilless cultivation can improve yield and quality, with cultivar selection playing an important role when utilising this production system.
\end{abstract}

Keywords: pH, Sugar content, Tomatoes, Yield

\section{INTRODUCTION}

In South Africa, tomatoes are not only cultivated commercially, but also grown by subsistence, resource poor farmers and home gardeners. Tomatoes are produced in all South African provinces. Limpopo is the major production area with 3590 ha (Northern Lowveld at 2700 ha and far northern areas of Limpopo at $890 \mathrm{ha}$ ). The other main producing areas are Overberg area of Mpumalanga Province and Border area of the Eastern Cape Province at 770 ha. Production is very limited in the winter months and tomatoes can only be produced in frostfree areas during winter or under protection (Department of Agriculture, Forestry and Fisheries (DAFF), 2013). Tomatoes are consumed in diverse ways including raw, as an ingredient in many dishes and sources, and also in drinks. In South Africa, tomatoes are used in stews to complement the staple diet of maize meal. As a result, it is also one of the main vegetables used

\footnotetext{
${ }^{1}$ Scientific Technician, Department of Rural Development and Agrarian Reform, Bathurst Satellite Station, Bathurst, South Africa, Email: Thozama.Bozo@drdar.gov.za

${ }^{2}$ Research Manager: Horticulture, Department of Rural Development and Agrarian Reform, Dohne Agricultural Development Institute, Stutterheim, South Africa, Email: babalwa.ntwana@drdar.gov.za

${ }^{3}$ Agricultural Advisor, Department of Rural Development and Agrarian Reform, Port Elizabeth, South Africa, Email: asiphembenga@gmail.com

${ }^{4}$ Research Manager: Agronomy, epartment of Rural Development and Agrarian Reform, Dohne Agricultural Development Institute, Stutterheim, South Africa, Email: simphiwe.mhlontlo@drdar.gov.za
} 
for hawking by small entrepreneurs in the informal settlement sector. Interestingly, although tomatoes are categorised as vegetables, they are botanically classified as fruit (DAFF, 2013).

Worldwide tomato production extends over 5.2 million ha, producing more than 130 million tons annually. In terms of tomato production, South Africa is ranked $39^{\text {th }}$ in the world, with a total of 421000 tons of tomatoes produced annually (Food and Agriculture Organisation (FAO), 2009). Soilless cultivation of fresh market tomatoes has gained popularity in recent years in South Africa due to improved growth, yield and quality of commodities grown in such systems (Maboko, Du Plooy \& Bertling, 2009).

The majority of South African producers cultivate tomato in the open field, with a small number producing in soilless systems under protection (Maboko et al, 2009). There is, however, an increase in soilless vegetable production (Raviv \& Lieth, 2008) since typical field-based monoculture systems often result in disease build-up, making the use of a soil based system a less suitable cultivation medium.

Many new tomato cultivars are released in South Africa and internationally. This results in a fast turnover rate of cultivars that can complicate cultivar choice. Different cultivars have different characteristics, including sensitivity to temperature extremes, tolerance or susceptibility to insects and diseases and fruit quality and size as well as yield (Niederwieser, 2001). Most tomato cultivars are imported into South Africa and therefore, the optimal growing conditions for specific cultivars need to be determined, as a wrong cultivar choice can lead to large financial loss.

In South Africa, the most popular hydroponic systems are the open-bag and the closed system using the gravel-film technique (Niederwieser, 2001). In closed systems, the excess nutrient solution is recovered, sometimes replenished and recirculated, while open systems do not recirculate the nutrient solution after it has passed the rooting zone. The open-bag system is generally used for production of an indeterminate growth habit, like tomatoes, sweet peppers, cucumbers and runner beans, while closed systems (using gravel-film technique) are generally used for leafy vegetables, such as lettuce, Swiss chards, spring onions as well as herbs.

Soilless cultivation has recently tended towards closed systems to avoid nutrient losses, thereby reducing potentially negative environmental impacts (Schwarz et al, 2008). To date, there is no information available on the performance of indeterminate fresh market tomato cultivars in closed hydroponic systems under local conditions.

\subsection{The objectives of the research study}

The research aimed to address the following research objectives:

- Determine the yield and quality of soil grown in a tomato cultivar under a semi-controlled environment.

- Determine the yield and quality of soilless grown tomatoes under a semi-controlled environment.

- Compare yield and quality of tomatoes grown in soil and soilless mediums under a semicontrolled environment. 
S. Afr. J. Agric. Ext.

Vol. 47 No. 4, 2019: 75 - 85

http://dx.doi.org/10.17159/2413-3221/2019/v47n4a527
Bozo, Mpambani,

Mbenga \& Mhlontlo

(License: CC BY 4.0)

\section{LITERATURE REVIEW}

\subsection{Production of tomatoes}

In South Africa, there are approximately 695 producers in both the commercial and emerging sectors (National Agricultural Marketing Council (NAMC), 2017). The commercial sector contributes $95 \%$ of the total produce while the emerging sector contributes only $5 \%$. According to FAO (2009), China is the largest producer of tomatoes in the world, followed by India, the United States, Turkey, Egypt, Iran and Italy. These countries represent more than $80 \%$ of world tomato production. Egypt is still the only African country amongst the top 10 world tomato producers (DAFF, 2013; DAFF, 2017). South Africa is a net importer of tomato paste, with the prevailing duties on imports of tomato paste from China which is currently $30 \%$ in cans $(28 \%$ - $30 \%$ brix) (NAMC, 2017). Importers feel vulnerable to the reaction of the exchange rates which is a dominant factor in pricing of imports of tomato paste, of which importers have no control over (DAFF, 2017). Domestic processors are able to produce tomato paste $(6 \mathrm{x}$ A10 3 $\mathrm{kg}$ tins) at a cost of R210 per unit. The same products can be imported from China at a lower price of R107.30 per unit (NAMC, 2017). In 2005, production of tomatoes in South Africa dropped by $4.5 \%$ and during 2007, the output dropped further by $5.1 \%$ (DAFF, 2013). From 2008 to 2010, production output increased steadily until 2011. The highest production output was recorded in 2012, and the increase was 9\% from the 2011 figures (DAFF, 2012). Over the past decade, tomato production was stable above 400000 tons per annum.

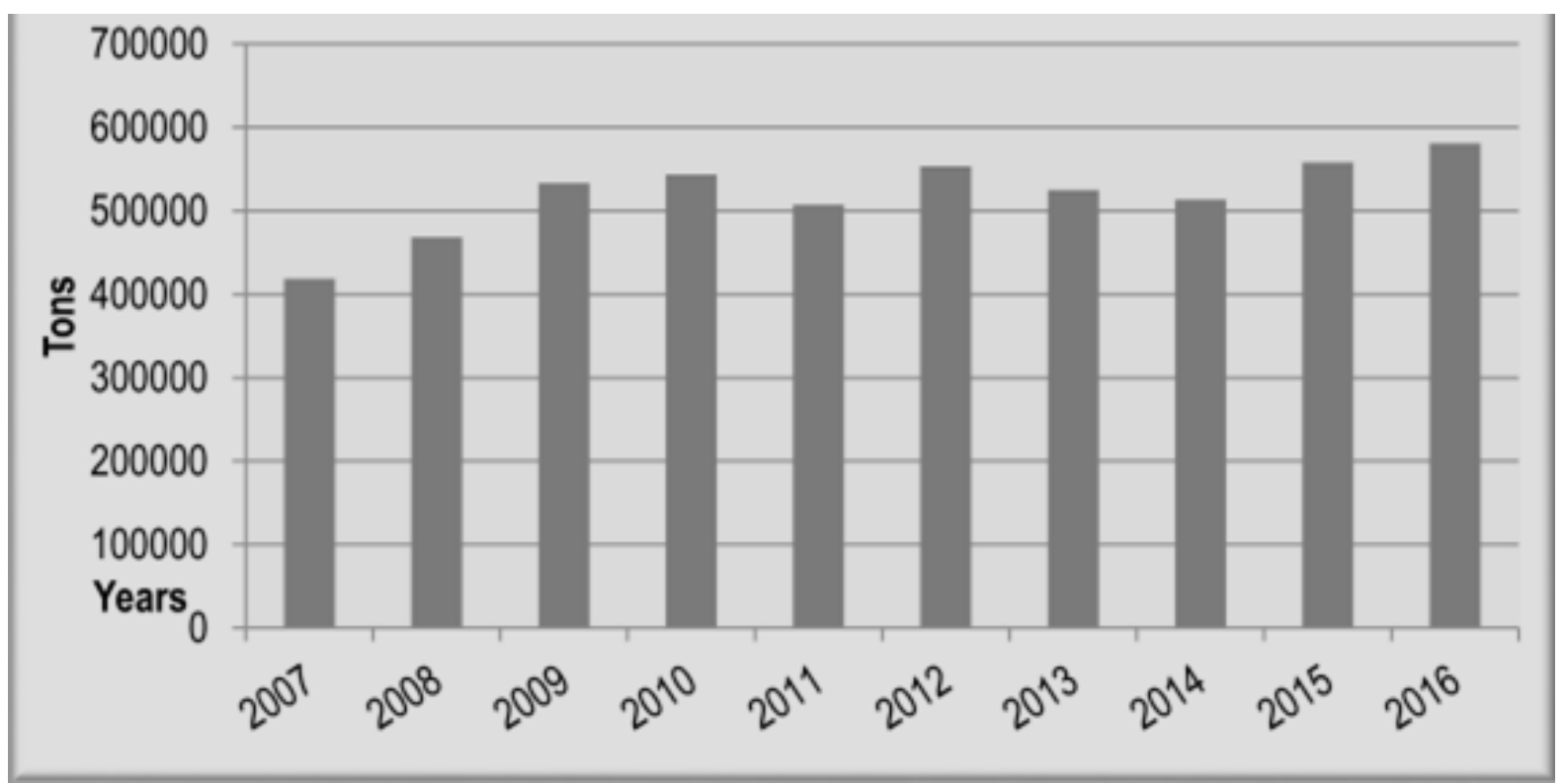

Figure 1: Total production of tomatoes in South Africa (DAFF, 2017)

\subsection{Factors affecting tomato production}

There are a number of factors which affect tomato production. Such factors include temperature, light, water and drought. However, these factors can be easily controlled through controlled environments. Factors affecting tomato production are discussed below. 


\subsubsection{Temperature and light}

Cracking of the tomato is significantly caused by a sudden increase in temperature and it increases as the fruit is exposed to higher temperatures. A significant increase in fruit cracking on the upper clusters has been observed by Peet and Willits (1995) with the percentage of fruit affected by cracking increasing from $21 \%$ (first cluster) to $38 \%, 41 \%$ and $45 \%$ for clusters 5 , 6 and 7 respectively. In addition, temperature and radiance were the factors that contributed to greater fruit cracking on the upper clusters. In an earlier review, Domis, Papadopoulos and Gosselin (2002) reported that the fluctuation of temperature, for instance low night temperature, favours a negative pressure in fruit, whereas high day temperature increases both gas and hydrostatic pressure of fruit pulp on the epidermis, resulting in cracking of the fruit. High temperatures play a role in reducing cuticle resistance and firmness (Dorais et al, 2004). Under high light conditions, fruit soluble solids and fruit growth rates are higher; both of these factors are associated with increased cracking (Peet, 1992). Pascual et al (2000) also confirmed that higher temperatures and higher radiation coincides with the reproductive period 'summer', which lead to a greater incidence of fruit cracking.

\subsubsection{Drought}

Drought is one of the most important limiting factors for agricultural crops and vegetable production all around the world. Large parts of the land in South Africa are semi-arid and are known to receive rainfall during the summer season. Water used for agricultural purposes has become scarcer and more expensive, especially for smallholder farmers and community projects. As a result, the need for efficient water use in agricultural production has become a major concern so as to reduce cost of water and scarcity (Johnson \& Leah, 1990). With South Africa's diverse climatic conditions and wide range of soil types, growing plants in open fields is unpredictable due to a wide range of challenges. These challenges include factors such as temperature, soil water holding capacity, cation exchange capacity, soils contaminated with heavy metals, available nutrient supply, proper root aeration, as well as disease and pest control which can be alleviated through the use of a soilless growing media under a protective environment (Du Plooy et al, 2012).

During water stress, many physiological and molecular processes are disturbed such as rootshoot growth, water relation, mineral absorption, leaf expansion and orientation, stomata behaviour, transpiration rate, photosynthesis and respiration rate. Due to drought stress, there is inhibition of cell division and enlargement leading to reduction in vegetative and reproductive growth, with leaf area and stem length reduced due to a decrease in cell size (Jangid \& Dwivedi, 2016). Many scientific studies have revealed that low water availability decreases the number of leaves, flowers and fruits in tomato cultivars. Fruit quality, shape, diameter and weight decreases under drought stress as compared to the normal condition. It has been noticed that production of tomatoes under protected environments in soilless media can resolve some of the problems faced by open field producers. According to Resh (2017), soilless production compared with traditional field allows the efficient use of water and nutrients by crops.

\subsection{Social benefits of soilless cultivation}

A soilless farming system is labour intensive, but not as hardy as a soil-based system such that women can easily participate in this farming system. Ploughing and weeding with hoes is also 
not done in a soilless system. This system has a greater flexibility in work because weather conditions such as rainfall do not hinder working in a soilless system, especially if it is done under plastic cover (Haq, 2009). Advantages of soilless cultures include more efficient regulation of nutrient and water supply, electric conductivity and $\mathrm{pH}$ of the nutrient solution, and temperature by the grower. Richard (2006) highlighted that a good growing medium must provide plants with adequate amounts of water, and enough porosity to supply oxygen and other gases to the roots. Most soilless growing mediums are affordable and can be reused for planting another crop after they are sterilised (Maboko, Bertling \& Du Plooy, 2013). Soilless culture therefore provides an ideal environment for growth and development of plants which often results in higher yield and quality compared to traditional methods. Growers in South Africa are faced with the challenge of producing high yields combined with good quality in order to satisfy local consumer demand, but due to poor cultivation methods, poor cultivar choice, inadequate plant nutrition, adverse climatic conditions, or pest and disease infestation, these demands are rarely met (Maboko et al, 2013).

\subsection{Growth substrate}

The significance of a hydroponic system in tomato production is that it enables the growers to manage water and nutrient supply and optimise the plant growth in a small production area. Organic growing media, namely sawdust, coir (cocos) and bark, are commonly used in open bag hydroponic systems although rapid corrosiveness and toxic substances found in sawdust are disadvantageous to plant growth and development (Niederwieser, 2001). However, Raviv (2014) affirmed that the use of sawdust has proven to have good plant performance compared to other wood wastes as a constituent of growing media. Maboko et al (2013) reported that organic growing media (sawdust and coir) did not have a significant effect on tomato yield as it has high porosity and water retention. In South Africa, sawdust is popular and readily available, especially in forested areas such as Mpumalanga and KwaZulu-Natal provinces.

The big challenge when selecting a growing medium is to combine the aeration and water holding capacity while taking into consideration the decomposition rate of organic matter in the media (Anlauf, Rehrmann \& Schacht, 2012; Niederwieser, 2001; Richard, 2006). Plants grown in a medium which is poorly aerated tend to be weaker, less succulent, produce undesirable fruits and are more susceptible to micronutrient deficiencies, root rot pathogens such as Pythium spp and Phytophthora spp than roots growing in well aerated media (Ingram, Henley \& Yeager, 1993). Tomatoes grown in soilless media were reported to outperform those grown in soil in terms of yield (Maboko et al, 2009). These researchers also reported that tomato plants grown in soil had a high incidence of fruit cracking and were severely infected by early blight fungal disease.

\subsection{Overview of hydroponic suitable for tomato production}

Hydroponics is defined as a technology for growing plants in nutrient solutions with or without the use of artificial media to provide mechanical support (Wittwer \& Castilla, 1995). The significance of a hydroponic system in tomato production is that it enables the growers to manage water and nutrient supply and optimise the plant growth in a small production area that is generally sub-optimal for plant growth, yield and quality (Maatjie, 2015). A suitable hydroponic for growth of tomato commonly used by most farmers is one that has sawdust (Hadley, Clinton \& Schwartz, 2003). However, the growing media must be amended to provide the appropriate physical and chemical properties necessary for plant growth (Mabengwa, 
2013). Trellising is also necessary as it supplies an artificial support to a growing plant to get sunlight, which is essential for photosynthesis and it also helps control the direction of the plants and provides a large surface area for growth and fruiting (Mahungu \& Otienede, 2004). The area or size of the tunnel is dependent on the preference of the farmer.

\section{MATERIALS AND METHODS}

\subsection{Bathurst Experimental Farm}

Mercury, Merya and Star 9037 cultivars were planted in 10 L plastic bags filled with sawdust as a growing medium. They were arranged in double row plots $100 \mathrm{~cm}$ apart, where a randomised design was replicated 12 times. Plants were fertigated four times a day using a dripper irrigation. A fertigation mixture consisting of Potassium sulphate, Calcium nitrate and hydrogro (mixture of trace elements) was used at an electrical conductivity of $1.2 \mathrm{mS} / \mathrm{cm}$ after planting, $1.8 \mathrm{mS} / \mathrm{cm}$ during active vegetative growth, and up to $2.5 \mathrm{mS} / \mathrm{cm}$ after fruit formation. After mixing in the tank, the $\mathrm{pH}$ (water) ranged between 5.5 to 6 . An $\mathrm{EC} / \mathrm{pH}$ meter was used to measure the electrical conductivity and $\mathrm{pH}$ of the solution. The irrigation system used was a drip irrigation. The plastic bags used to contain the sawdust can be any colour (black, white, colourless), however, the plastic bags in Bathurst were black in colour. They were placed on top of black plastic which is called the mulch in order to prevent germination of weeds as well as soil borne diseases such as nematodes or eelworms. A twine was used to trellis the plants so as to direct them in an upright position until they were $2 \mathrm{~m}$ high.

\subsection{Masiphathisane Community Project}

This is a community based project that has recently been resuscitated in 2018 and it consists of seven members. It is situated in Bathurst under Sarah Baartman District Municipality. The project has three $30 \mathrm{~m}$ by $10 \mathrm{~m}$ tunnels which were used to plant tomatoes directly in the soil, but soluble fertilizers and drip irrigation for fertilizer application were used. Soil preparation was done by making ridges using spades and rakes and the distance between ridges was 100 $\mathrm{cm}$. SV4129 cultivar was planted at inter and intra row spacing of $40 \mathrm{~cm}$ and $30 \mathrm{~cm}$ respectively. The seedlings were brought from the local seedling nursery in East London. A fertigation mixture consisting of Potassium sulphate, Calcium nitrate and hydrogro (mixture of trace elements) was used at an electrical conductivity of $1.2 \mathrm{mS} / \mathrm{cm}$ after planting, $1.8 \mathrm{mS} / \mathrm{cm}$ during active vegetative growth, and up to $2.5 \mathrm{mS} / \mathrm{cm}$ after fruit formation. A twine was used to trellis the plants so as to direct them in an upright position until they were $2 \mathrm{~m}$ high.

\subsection{Data collection}

At maturity, fruits were harvested weekly and data were collected to measure yield, sugar content (\% Brix) and $\mathrm{pH}$ of tomato juices in both sites.

\section{RESULTS AND DISCUSION}

\subsection{Bathurst Experimental Farm}

The results obtained in this study showed differences in yield of the cultivars with Mercury having the highest yield of $9 \mathrm{~kg} / \mathrm{plant}$ followed by Star 9037 with $8.6 \mathrm{~kg} / \mathrm{plant}$ and Merya being the least with $6.4 \mathrm{~kg} /$ plant. Although the cultivars yielded differently, there was no significant 
difference between the cultivars (Figure 2). A similar trend was found by Saleem, Asghar and Iqbal (2013). Akinfasoye et al (2011) also found a highly significant positive association between number of fruits per plant and fruit yield $(\mathrm{kg})$ per plant. A significantly higher sugar content (\% Brix) was obtained in Merya (5.7\%) and the lowest was obtained in Star 9037 (4.8\%), while Mercury recorded 5.2\%. Star 9037 and Merya showed highly significant differences between each other although they both showed no significant difference to Mercury (Figure 3). Therefore, the sugar content of these cultivars is still acceptable, as the \%Brix for tomatoes grown in greenhouses, using the film technique, can vary from 4.7 to $5.1 \%$ Brix (Domis et al, 2002). Chernet, Belew and Abay (2013) also reported a wide range of differences in number of fruits, yield and quality per plant in tomato cultivars. Generally, association of characters indicated that fruit yield per plant, number of fruits per plant, number of fruit clusters per plant, and shape index are the most important fruit yield components which contributes more to highest fruit yield and quality per hectare. The $\mathrm{pH}$ (water) among the cultivars varied from 5.98 (Merya) to 6.08 (Mercury) and there was no significant difference among the cultivars (Figure 4). Jones (2007) reported that the lower the $\mathrm{pH}$, the greater the tartness of the fruit, a factor by which the consumers judge the quality of tomato fruit. Sugars, acids and sugar/acid ratios have been defined as good indicators of tomato flavour. According to Jones (2007), the acceptable $\mathrm{pH}$ range of tomato juice averages between 4.0 to 4.5. Our findings revealed highest $\mathrm{pH}$ ranges, which could be a result of harvesting stage as the fruit was ripen during harvesting (Figure 4).

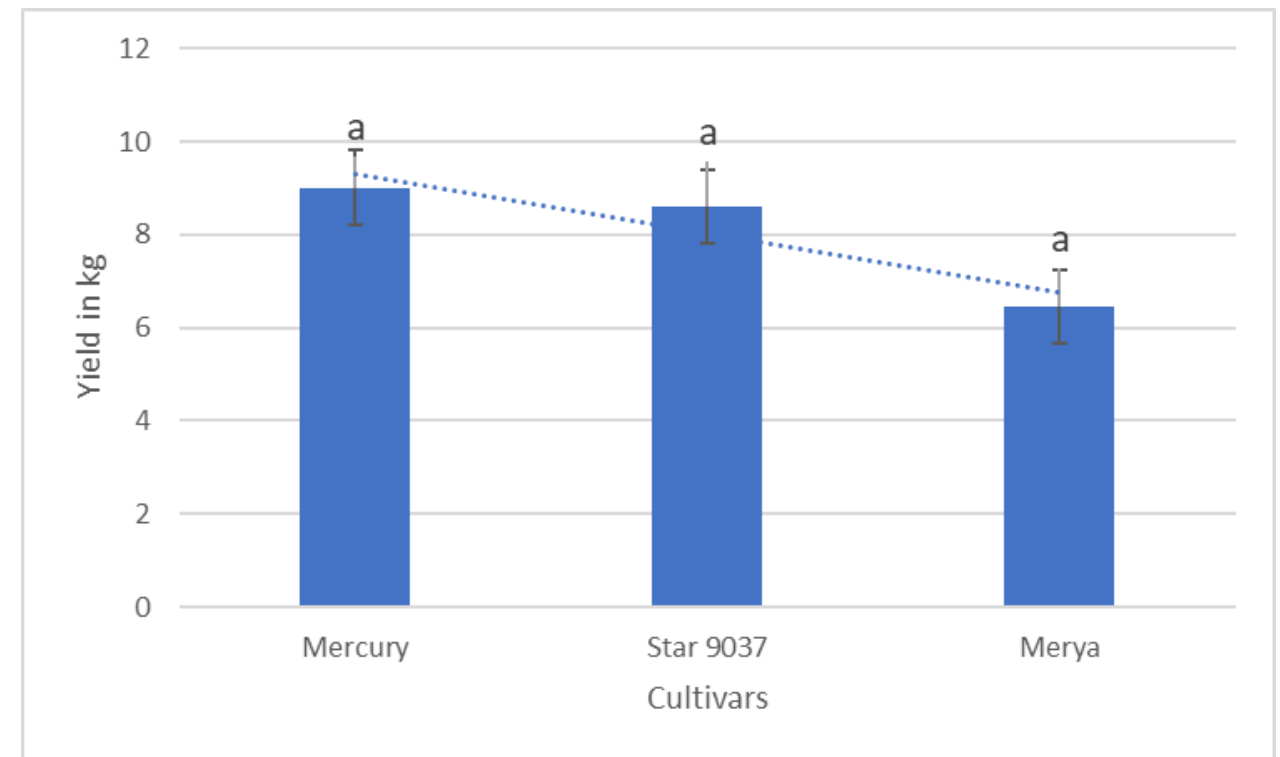

Figure 2: Yield per plant (kg) of different cultivars at Bathurst Experimental Farm 
S. Afr. J. Agric. Ext.

Vol. 47 No. 4, 2019: 75 - 85

http://dx.doi.org/10.17159/2413-3221/2019/v47n4a527
Bozo, Mpambani,

Mbenga \& Mhlontlo

(License: CC BY 4.0)

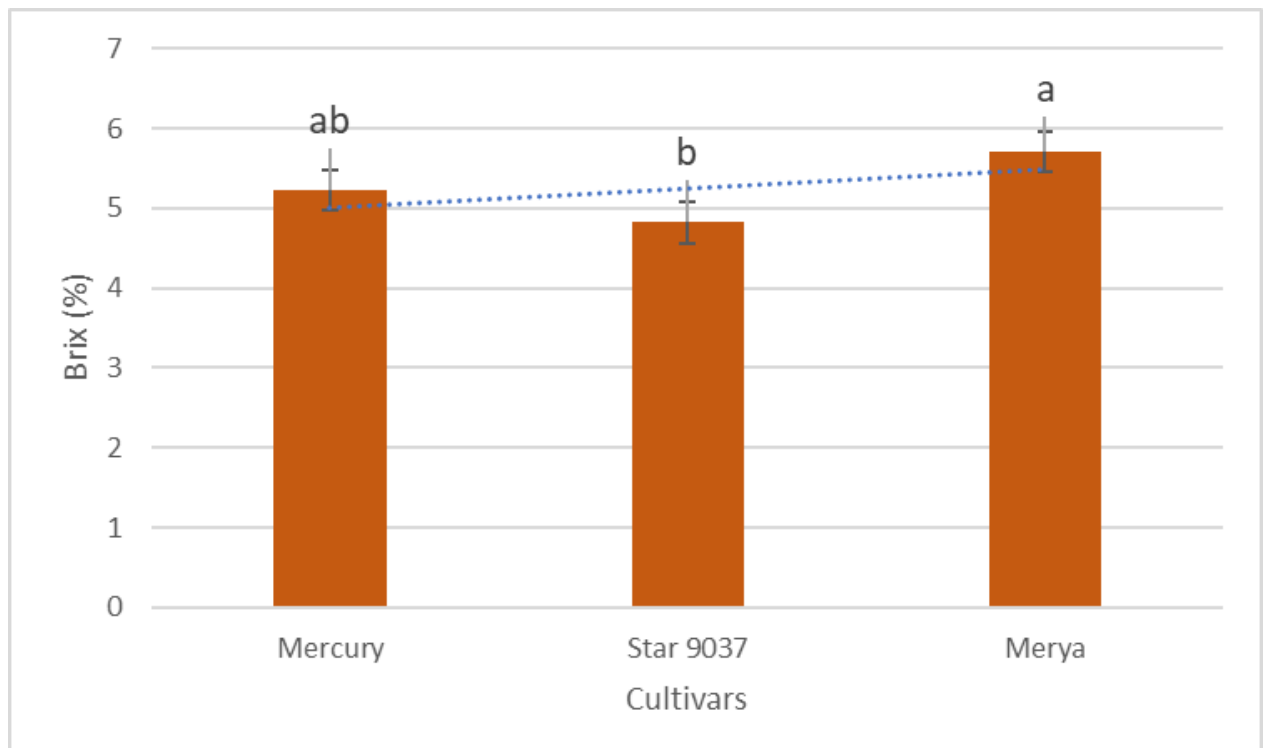

Figure 3: Sugar content measured by \%Brix in different cultivars at Bathurst Experimental farm

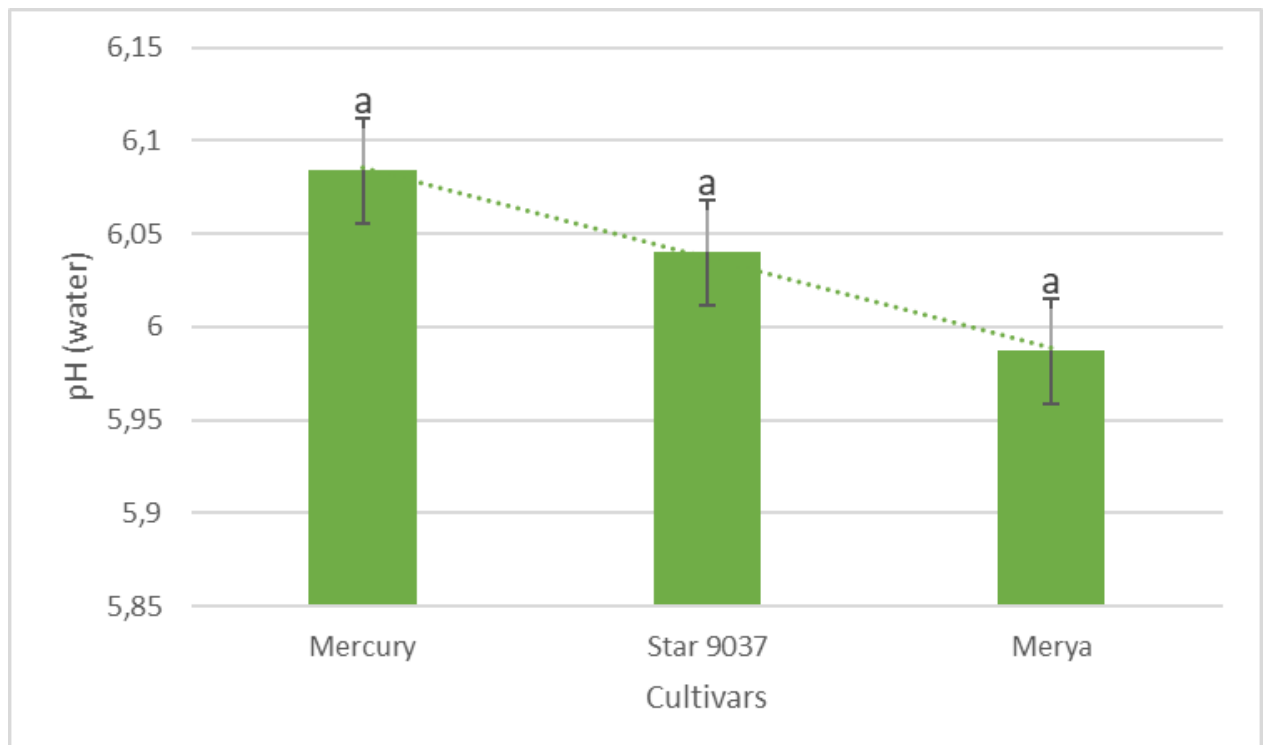

Figure 4: pH (water) in different cultivars at Bathurst Experimental Farm

\subsection{Masiphathisane Community Project}

The average yield of cultivar SV4129 was $6.5 \mathrm{~kg}$ per plant, while sugar content as measured by $\%$ Brix was 5.1. The $\mathrm{pH}$ was found to be 5.52. The yield obtained in Masiphathisane Community Project was similar to that obtained in Merya cultivar $(6.4 \mathrm{~kg})$ at Bathurst Experimental Farm. However, this yield is significantly lower than that obtained from Mercury $(9 \mathrm{~kg})$ at Bathurst Experimental Farm. Similarly, the sugar content of 5.2\%Brix was within the range of 4.8 and 5.7 \%Brix in Star 9037 and Merya cultivars respectively. 


\section{CONCLUSION AND RECOMMENDATIONS}

Cultivars Mercury and Merya can be selected and recommended for high yields and high sugar content respectively in soilless production. Cultivar SV4129 has a better pH level of 5.52 compared to other cultivars, namely Mercury (6.09), Merya (9037) and Star 9037 (6.05). Yield obtained from SV4129 at Masiphathisane in soil grown tomato was found to be lower than that obtained in Bathurst Experimental Farm in soilless cultivation, but still within the range obtained in soilless cultivation. However, the cultivar planted in soil conditions was not tested in soilless cultivation. For conclusive results, same cultivars tested in soilless conditions should be tried in soil cultivation. Furthermore, if the soil is not a limiting factor, the system employed in Masiphathisane Community Project can be recommended because it is less expensive yet the yield, sugar content and $\mathrm{pH}$ are similar to those obtained under the soilless system.

\section{ACKNOWLEDGEMENTS}

Mr B. Kombisa is acknowledged for his assistance during planting, as well as horticulture interns (Mr K.B. Jokazi and Miss Z. Nkolisa) for assisting with information. Dr M. Mbangcolo is acknowledged for the assistance with the statistical analysis.

\section{REFERENCES}

AKINFASOYE, J., DOTUN, A., OGUNNIYAN, J. \& AJAYI, E.O., 2011. Phenotypic relationship among agronomic characters of commercial tomato (lycopersicum esculentum) hybrids. Am. Eurasian J. Agron., 4(1):17-22.

ANLAUF, R., REHRMANN, P. \& SCHACHT, H., 2012. Simulation of water uptake and redistribution in growing media during ebb-and-flow irrigation. J. Hortic. For., 4(1):821.

CHERNET, S., BELEW, D. \& ABAY, F., 2013. Genetic variability and association of characters in tomato (Solanum lcopersicon L.) genotypes in Northern Ethiopia. Int. J. Agric. Res., 8(2):67-76.

DEPARTMENT OF AGRICULTURE, FORESTRY AND FISHERIES (DAFF), 2012. A profile of South African tomato market value chain. Available from: https://www.nda.agric.za/doaDev/sideMenu/Marketing/Annual\%20Publications/Comm odity\%20Profiles/field\%20crops/Tomato\%20Value\%20Chain\%20Profile\%20\%202012 .pdf

DEPARTMENT OF AGRICULTURE, FORESTRY AND FISHERIES (DAFF), 2013. A profile of South African tomato market value chain. Available from: https://www.nda.agric.za/doaDev/sideMenu/Marketing/Annual\%20Publications/Comm odity\%20Profiles/field\%20crops/Tomato\%20Market\%20Value\%20Chain\%20Profile\% 202013.pdf

DEPARTMENT OF AGRICULTURE, FORESTRY AND FISHERIES (DAFF), 2017. A profile of South African tomato market value chain. Available from: https://www.nda.agric.za/doaDev/sideMenu/Marketing/Annual\%20Publications/Comm odity\%20Profiles/field\%20crops/Tomato\%20Market\%20Value\%20Chain\%20Profile\% 202017.pdf 
DOMIS, M., PAPADOPOULOS, A.P. \& GOSSELIN, A., 2002. Greenhouse tomato fruit quality. Horticult. Rev., 26:239-349.

DORAIS, M., DEMERS, D.A., PAPADOPOULOS, A.P. \& VAN IEPEREN, W., 2004. Greenhouse tomato fruit cuticle cracking. Horticult. Rev., 30:163-183.

DU PLOOY, C.P., MABOKO, M.M., VAN DEN HEEVER, E. \& CHILOANE, S., 2012. Research and technology transfer by Agricultural Research Council to sustain South African hydroponic industry. Acta Hortic., 947:147-151.

FOOD AND AGRICULTURE ORGANISATION (FAO), 2009. Available from: http://www.fao.org/statistics/en/

HADLEY, C.W., CLINTON, S.K. \& SCHWARTZ, S.J., 2003. The consumption of processed tomato products enhances plasma lycopene concentrations in association with a reduced lipoprotein sensitivity to oxidative damage. J. Nutr., 133(3):727-732.

HAQ, A.M.M.R., 2009. Some thoughts on soilless agriculture in Bangladesh. Bangladesh: Wetland Resource Development Society.

INGRAM, D., HENLEY, R.W. \& YEAGER, T.H., 1993. Growth media for container grown ornamental plants. IFAS Bulletin 241. University of Florida.

JANGID, K.K. \& DWIVEDI, P., 2016. Physiological response of drought stress in tomato: A review. IJAEB., 9(1):53-61.

JOHNSON, M.S. \& LEAH, R.T., 1990. Effects of superabsorbent polyacrylamides on efficiency of water use by crop seedlings. J. Sci. Food Agric., 52(3):431-434.

JONES, J.B., 2007. Tomato plant culture: In the field, greenhouse, and home garden. 2nd ed. Florida: CRC Press LLC.

MAATJIE, M.A., 2015. Growth, yield and quality of hydroponically grown tomatoes as affected by different particle sizes of sawdust. MSc Thesis, University of South Africa.

MABENGWA, M., 2013. Growth responses of tomato to different growing media under greenhouse and field conditions. M.Agronomy Thesis, University of Zambia.

MABOKO, M.M., BERTLING, I. \& DU PLOOY, C.P., 2013. Arbuscular mycorrhiza has limited effects on yield and quality of tomatoes grown under soilless cultivation. Acta Agric. Scand. B., 63(3):261-270.

MABOKO, M.M., DU PLOOY, C.P. \& BERTLING, I., 2009. Comparative performance of tomato on soilless vs in-soil production systems. Acta Hortic., 843:319-326.

MAHUNGU, R.M. \& OTIENEDE, J.E., 2004. Learn how to grow Yams. Wagenigen: Technical Centre for Agricultural and Rural Co-operation.

NATIONAL AGRICULTURAL MARKETING COUNCIL (NAMC), 2017. The South African tomato value chain. Available from: https://www.namc.co.za/wpcontent/uploads/2017/09/The-South-African-Tomato-Value-chain-Study.pdf

NIEDERWIESER, J.G., 2001. Guide to hydroponic vegetable production. 2nd ed. Pretoria: Agricultural Research Council.

PASCUAL, B., MAROTO, J.V., SANBAUSTISTA, A., LOPEZ-GALARZA, S. \& ALAGARDA, J., 2000. Influence of watering on the yield and cracking of cherry, fresh market and processing tomatoes. J. Hortic. Sci. Biotechnol., 75(2):171-175. 
S. Afr. J. Agric. Ext.

Vol. 47 No. 4, 2019: 75 - 85

http://dx.doi.org/10.17159/2413-3221/2019/v47n4a527
Bozo, Mpambani, Mbenga \& Mhlontlo (License: CC BY 4.0)

PEET, M.M., 1992. Fruit cracking in tomato. HortTechnology, 2(2):216-223.

PEET, M.M. \& WILLITS, D.H., 1995. Role of excess water in tomato fruit cracking. HortScience, 30(1):65-68.

RAVIV, M., 2014. Building and maintaining soil health in the context of organic greenhouses. Acta Hortic., 104(1)79-86.

RAVIV, M. \& LIETH, J.H., 2008. Soilless culture theory and practice. Amsterdam: Elsevier.

RESH, H., 2017. Hydroponics, questions and answers for successful growing. United Kingdom: Routledge.

RICHARD, M.P., 2006. Effect of nursery media particle size distribution on container-grown woody ornamental production, MSc Thesis, Louisiana State University.

SALEEM, M.Y., ASGHAR, M. \& IQBAL, Q., 2013. Augmented analysis for yield and some yield components in tomato (Lycopersicon esculentum Mill.). Pak. J. Bot., 45(1):215218.

SCHWARZ, D., FRANKEN, P., KRUMBENEIN, A., KLÄRING, H.P. \& BAR-YOSEF, B., 2008. Nutrient management in soilless culture in the conflict of plant, micro-organism, consumer and environmental demands. Acta Hortic., 843:27-34.

WITTWER, S.H. \& CASTILLA, N., 1995. Protected cultivation of horticultural crops worldwide. HortTechnology, 5(1):6-23. 
